\title{
Extract of Solidago chilensis Meyen inflorescences: cytotoxicity and inhibitory activity on nitric oxide synthesis in activated macrophage cell line J774A.1
}

\author{
Thais Morais de Britoํㅡ, Fabio Coelho Amendoeira', \\ Temistocles Barroso de Oliveira ${ }^{2}$, Valber da Silva Frutuoso ${ }^{3}$, \\ Fausto Klabund Ferraris ${ }^{(* * 1}$, Simone Sacramento Valverde*2 \\ ${ }^{1}$ Laboratório de Farmacologia, Instituto Nacional de Controle de Qualidade em Saúde - FIOCRUZ, \\ Rio de Janeiro, Brazil, ${ }^{2}$ Laboratório de Química Medicinal de Produtos Bioativos - LAQMED, \\ Departamento de Produtos Naturais, Instituto de Tecnologia em Fármacos - FIOCRUZ, Rio de Janeiro, \\ Brazil, ${ }^{3}$ Laboratório de Imunofarmacologia, Instituto Oswaldo Cruz - FIOCRUZ, Rio de Janeiro, Brazil
}

\begin{abstract}
Solidago chilensis Meyen (= Solidago microglossa) popularly known as "Brazilian arnica" is used to treat of inflammatory disorders. S. chilensis is constant in the Therapeutic Memento of the Rio de Janeiro city and belongs to the medicinal species of Brazilian National List of Medicinal Plants of Interest of the Unified National Health System (SUS). There are no studies in the literature showing the direct activity of this plant species on immune system cells. The present study evaluated the chemical composition as well as the cytotoxic and pharmacological activity of the ether-ethanol extract from $S$. chilensis inflorescences (SCIE) in murine macrophage cell line J774A.1. The results showed that higher concentrations (50 to $200 \mu \mathrm{g} / \mathrm{mL}$ ) of SCIE had significant cytotoxicity on J774A.1 cells, however, lower concentrations (from 10 to $0.1 \mu \mathrm{g} / \mathrm{mL}$ ) did not produce significant cytotoxic effects and exhibited an inhibitory effect on nitric oxide production in LPS-stimulated J774A.1 cell line. The chemical analysis by HPLC-UV-PDA indicated that the SCIE contains flavonoid derived from quercetin and kaempferol; and diterpenes, probably labdanes. These findings complement data in the literature regarding the activity of this plant species on an important cell from the immune system involved in the innate and acquired immune response, the macrophages.
\end{abstract}

Keywords: Anti-inflammatory activity. Medicinal plant. Asteraceae. Diterpenes. Flavonoids.

\section{INTRODUCTION}

Solidago chilensis Meyen is a member of the Asteraceae family widely used in Brazilian folk medicine, as well as in other countries of North and South America. This plant species is part of the Brazilian

\footnotetext{
*Correspondence: F. K. Ferraris, Departamento de Farmacologia e Toxicologia, Instituto Nacional de Controle de Qualidade em Saúde, Fundação Oswaldo Cruz, Av. Brasil, 4365 - Manguinhos, Rio de Janeiro, Brasil. E-mail: fausto.ferraris@incqs.fiocruz.br. S. S. Valverde, Departamento de Produtos Naturais, Instituto de Tecnologia em Fármacos, Fundação Oswaldo Cruz, Rua Sizenando Nabuco, 100 - Manguinhos, Rio de Janeiro, Brasil. E-mail: simone.valverde@far.fiocruz.br. Both authors contributed equally to this work.
}

National List of Medicinal Plants of Interest to Unified National Health System (RENISUS). It is largely used in folk medicine as a diuretic and to treat burns, skin diseases, edemas and inflammatory pathologies such as rheumatism (Corrêa, 1984; Mors, Rizzini, Pereira, 2000; Facury Neto et al., 2004; Lorenzi, Matos, 2008).

Macrophages are highly versatile immune cells that play a key role in the innate immune response system. They form a bridge between innate and acquired immune response systems. In inflammation, macrophages participate actively in the inflammatory response and have many functions, such as antigen presentation, phagocytosis, and immunomodulation 
through production of various cytokines, growth factors, lipid mediators, reactive oxygen species (ROS) and nitric oxide (NO) (Oishi, Manabe, 2018).

Little is known about the effect of $S$. chilensis on the cells from the immune system. Results about the anti-inflammatory activity of $S$. chilensis suggest a mechanism of action related to reduction of some soluble inflammatory mediators such as TNF- $\alpha$, IL- $1 \beta$ and NO, associated with impairment of the effective neutrophil mobilization to the site of injury (Goulart et al., 2007; Liz et al., 2008; Tamura et al., 2009). Nevertheless, there are no in vivo or in vitro studies showing the direct effect of $S$. chilensis on immune cells such as lymphocytes, macrophages or dendritic cells.

In the present study, we evaluated the in vitro toxicity of the ether-ethanol extract from S. chilensis inflorescences (SCIE) on a cell lineage of murine macrophages. In addition, we were able to observe the activity of this extract to modulate the NO production in lipopolysaccharide (LPS)-stimulated cells. Finally, a chemical analysis was performed to determine the phytochemical constituents of the SCIE.

\section{MATERIAL AND METHODS}

\section{Plant Material and extraction}

S. chilensis were cultivated in Itaboraí Palace (PIT/Fiocruz) in Vale do Cuiabá, Petrópolis' (RJ) (22 ${ }^{\circ}$ 23'10.19''S; 43 3'27.14' W). The determination of the species was made by Dr. Sergio da Silva Monteiro and a voucher was deposited in the Herbarium of Universidade Federal do Rio de Janeiro, under the number: RFA 39.930 (Collection 1/2016 - RFA 39.930). The study of the plant material was conducted under the register of Brazilian System for Management of Genetic Heritage and Associated Traditional Knowledge (SISGEN) (Process number AF96E16).

Inflorescences of $S$. chilensis $(200 \mathrm{~g})$ were collected and dried in an oven with circulating air flow between 35 $40{ }^{\circ} \mathrm{C}$ and pulverized in a knife mill. After pulverization, the sample was extracted by dynamic maceration with ether:ethanol (1:1) for $6 \mathrm{~h}$ (Valverde, Azevedo, Tomassini, 2009). The crude ether:ethanol extract obtained from the filtrate was subjected to evaporation under reduced pressure in a rotary evaporator (BÜCHI R-124).

The dried extract was obtained in a rotary evaporator aliquots and subjected to preliminary chromatographic phytochemical analysis, by thin layer chromatography
(TLC), compared to standard compounds: quercetin - Sigma-Aldrich ${ }^{\mathrm{TM}}$ and solidagenone (isolated and quality controlled) as recommended by the Brazilian Health Regulatory Agency (ANVISA) (BRASIL, 2017) - as the standard is not commercially available. The TLCs were physically developed under UV lamp, and reagent solutions were employed to characterize their different phytochemicals using NP-PEG for flavonoids and sulfuric anisaldehyde for the terpenes (Wagner, Bladt, 1996). The 1,1-diphenyl-2-picrylhydrazyl $(\mathrm{DPPH})$ reagent solution identified constituents with antioxidative activity. TLC plates precoated with silica gel F254 (Merck ${ }^{\mathrm{TM}}$ ) were employed. All solvents used in this work were P.A. grade (Tedia' $\left.{ }^{\mathrm{TM}}\right)$.

\section{HPLC-UV-PDA analysis}

The HPLC-UV-PDA analysis of SCIE was carried out through two different methodologies, one developed by Apáti et al. (2002) to characterize flavonoids and phenolic substances in Solidago canadensis and another developed by Valverde et al., (2009) to characterize labdane diterpenes, commonly found in S. chilensis.

HPLC-UV-PDA analysis was performed with LiChrospher 100 RP-18 $5 \mu \mathrm{m}$ column $\left(\right.$ Merck $^{\mathrm{TM}}$, CL0136) for analytical scale with $250 \mathrm{~mm}$ length, $4 \mathrm{~mm}$ diameter and $5 \mathrm{~mm}$ particle size using $\mathrm{C} 18$ as stationary phase and PDA detector, type SPD-M20A. A binary mixture was used as the eluent system, composed of acetic acid:water (1:40) and acetonitrile, for analysis of flavonoids (Apáti et al., 2002) and $0.05 \%$ trifluoroacetic acid $(54.94 \mathrm{~mL})$ and acetonitrile $(27.06 \mathrm{~mL})$ for the terpenoids. (Valverde, Azevedo, Tomassini, 2009).

Samples were diluted in the ratio of $10 \mathrm{mg} / \mathrm{mL}$ and $10 \mu \mathrm{L}$ aliquots were injected. The separation occurred at $25^{\circ} \mathrm{C}$, with a flow of $1 \mathrm{~mL} /$ minute. The eluted substances were analyzed for their absorption in UV at $310 \mathrm{~nm}$ for flavonoids and in UV at $225 \mathrm{~nm}$ for terpenoids.

\section{SIM-Q-TOF-ESI analysis}

The spectrometry analysis was performed by electrospray ionization to identify directly and simultaneously the presence of flavonoids in the samples. It was conducted through selective ion monitoring, while using combining quadrupoles, as well as mass spectrometers by ESI and ion-traps, with TOF analyzers, leading to the selection of a molecular mass range of the compounds to be identified. 
The samples were dissolved with methanol (until $10 \mathrm{ppm}$ ), using selective ion monitoring (SIM) scanned from 50 to $1500 \mathrm{~m} / \mathrm{Z}$, in the positive mode polarity, 4.0 Bar (set nebulizer), $200{ }^{\circ} \mathrm{C}$ (set dry heater), $9.0 \mathrm{~L} / \mathrm{min}$ (set dry gas), $0{ }^{\circ} \mathrm{C}$ heater (set APCI), at inactive focus mode. In HPLC analysis, the samples were diluted to 10 $\mathrm{mg} / \mathrm{mL}$ and $10 \mu \mathrm{L}$ was injected.

\section{Cell culture}

Murine macrophage cell line J774A.1 (ATCC TIB$67^{\mathrm{TM}}$ ) was maintained at Dulbecco's minimal essential medium (DMEM) with $10 \%$ FBS, and antibiotic mixture (Penicillin, streptomycin and ampicillin 100 units $/ \mathrm{mL}$ ), under pre-defined conditions of temperature at $37{ }^{\circ} \mathrm{C}$, $95 \%$ humidity and $5 \% \mathrm{CO}_{2}$.

\section{Cytotoxicity assay}

The SCIE cytotoxicity was performed in murine macrophages J774A.1 (ATCC TIB-67) by the Alamar Blue $^{\mathrm{TM}}$ assay. Cells were cultured in DMEM medium (Dulbecco's Modified Eagle medium) supplemented with $10 \%$ fetal bovine serum, $2 \mathrm{mM}$ glutamine, $100 \mu \mathrm{g} / \mathrm{mL}$ streptomycin and $100 \mathrm{U} / \mathrm{mL}$ penicillin, and incubated at $37{ }^{\circ} \mathrm{C}$, in an atmosphere of $5 \% \mathrm{CO}_{2}$. To evaluate of cytotoxicity, cells were seeded in 96 well plates $(5 \times 104$ cells/well) and incubated with the SCIE at concentrations of $1 ; 10 ; 50 ; 100$ and $200 \mu \mathrm{g} / \mathrm{mL}$ in final volume of $200 \mu \mathrm{L}$ for 48 hours in a $5 \% \mathrm{CO}_{2}$ incubator at $37^{\circ} \mathrm{C}$. As controls, cells were incubated only with culture medium (positive control of cell viability) or with culture medium containing $0.5 \%$ dimethyl sulfoxide (DMSO), used in the dilution of the extract. After 44 hours, $20 \mu \mathrm{L}$ of Alamar Blue solution was added and incubated for 4 hours. The fluorescence signal was monitored through a multi-plate reader using excitation wavelength 530 - 560 $\mathrm{nm}$ and $590 \mathrm{~nm}$ emission wavelength. The fluorescent signal generated from the assay was proportional to the number of viable cells in the sample. The assay was performed in quadruplicate.

\section{Nitric oxide production}

J774A.1 cell lineage was seeded in a 96 well plate $\left(2.5 \times 10^{5}\right.$ cells/well) and incubated with the SCIE at concentrations of $0.01 ; 0.1 ; 1$ and $10 \mu \mathrm{g} / \mathrm{mL}$ for 1 hour. Dexamethasone $(50 \mathrm{nM})$ was used as a reference antiinflammatory drug. After 1 hour of treatment, the cells were stimulated with LPS $(1 \mu \mathrm{g} / \mathrm{mL})$ and maintained in culture for 24 hours in a $5 \% \mathrm{CO}_{2}$ at $37^{\circ} \mathrm{C}$. The production of nitric oxide was determined in the supernatants by the Griess method. The reading was performed in a spectrophotometer with absorbance of $570 \mathrm{~nm}$.

\section{Statistical analysis}

The data is reported as the mean \pm standard error of the mean (SEM) and was statistically analyzed by one-way ANOVA test and Tukey's post hoc test was used for comparisons. $\mathrm{P}$ values $<0.05$ were considered significant. The data were determined using Graph Pad Prism 5.0 software (Graph Pad Prism Software Inc.).

\section{RESULTS AND DISCUSSION}

\section{Evaluation of cell toxicity induced by SCIE}

To perform an in vitro assay with SCIE, we first examined the cytotoxic effects of this extract on J774A.1 macrophage cell line at concentrations of 1 to $200 \mu \mathrm{g} / \mathrm{mL}$. As shown in Table I, concentrations of 100 and $200 \mu \mathrm{g} / \mathrm{mL}$ of SCIE had a cytotoxic effect, indicating significant reduction of the surviving cells (71 and $100 \%$ dead cells, respectively). Concentration of $50 \mu \mathrm{g} /$ $\mathrm{mL}$ had a cytotoxicity close to $20 \%$ ( $18.5 \%$ of toxicity), whereas other concentrations tested were non-toxic, at cell viability higher than $90 \%(10 \mu \mathrm{g} / \mathrm{mL}$ : $95.5 \%$ and $1 \mu \mathrm{g} / \mathrm{mL}: 100 \%$ viable cells).

S. chilensis is considered toxic and may cause hemorrhage and uterine contraction; thus, it is contraindicated during pregnancy (Lorenzi, Matos, 2008). For this reason, its internal use should be done with strict indication and medical follow-up (Lorenzi, Matos, 2008). In the scientific literature, toxicity studies with $S$. chilensis have shown quite divergent results. No cytotoxic activity was found in an in vitro study with human fibroblasts incubated with crude extract (Martins et al., 2009). However, infusions of $S$. chilensis leaves presented cytotoxic and antiproliferative activity in the Allium cepa assay (Bagatini et al., 2008) as well as hemolytic effects in human erythrocytes (De Freitas et al., 2008). When evaluated in vivo, the aqueous and ethanolic extract demonstrated no signs of acute toxicity in orally treated mice (Zaneti et al., 2003). On the other hand, aqueous and hydroalcoholic extract administration (in doses higher than $100 \mathrm{mg} / \mathrm{kg}$ ) reduced locomotor activity (Assini, Fabrício, Lang, 2013) and induced 
alterations in the spleen and in the liver of treated mice (Paula-Freire et al., 2014).

TABLE I - Cytotoxic effect of SCIE on the cell line J774A.1

\begin{tabular}{lcc}
\hline Sample & $(\boldsymbol{\mu g} / \mathbf{m L})$ & $(\mathbf{\%})$ \\
\hline Medium & - & 100 \\
DMSO $(0.5 \%)$ & - & 100 \\
\hline & 200 & 0 \\
& 100 & 29 \\
SCEI & 50 & 81.5 \\
& 10 & 100 \\
& 1 & 100 \\
\hline
\end{tabular}

Results were expressed as percentage of viable cells (\%). J774A.1 line ( $2.5 \times 10^{5}$ cells/well) was incubated for 48 hours with different concentrations of the SCIE or $0.5 \%$ of DMSO as control vehicle $\left(37^{\circ} \mathrm{C}, 5 \% \mathrm{CO}_{2}\right)$. The results are expressed from quadruplicate wells.

\section{SCIE inhibit nitric oxide synthesis in LPS-stimulted macrophages}

To investigate the effect of $S$. chilensis on macrophage activation, we evaluated the ability of SCIE to modulate the NO production on LPS-stimulated J774A.1 macrophages. Concentrations with toxicity less than $10 \%$ were used to perform the LPS-stimulated macrophage assay.

The stimulation of LPS $(1 \mu \mathrm{g} / \mathrm{mL})$ to J774A.1 cells induced a significant increase in the production of nitrite ( $p<0.05$ ). Following that, dexamethasone inhibited nitrite production at levels close to the non-stimulated control (medium) (Figure 1). Treatment of J774A.1 cells with SCIE (1 h before stimulation) demonstrated inhibitory activity against LPS stimulation at the concentration of $0.1 \mu \mathrm{g} / \mathrm{mL}$ with a maximal inhibitory effect of $10 \mu \mathrm{g} / \mathrm{mL}$ (Figure 1).

Some authors have already verified reduction of NO levels on exudates obtained from animals treated with S.chilensis and challenged with carrageenan. However, they obtained few results involving the direct effect of the $S$. chilensis extract on immune system cells (Goulart et al., 2007; Liz et al., 2008). To date, data from the literature indicates that the decrease in neutrophilic infiltrate is related to decreased interaction

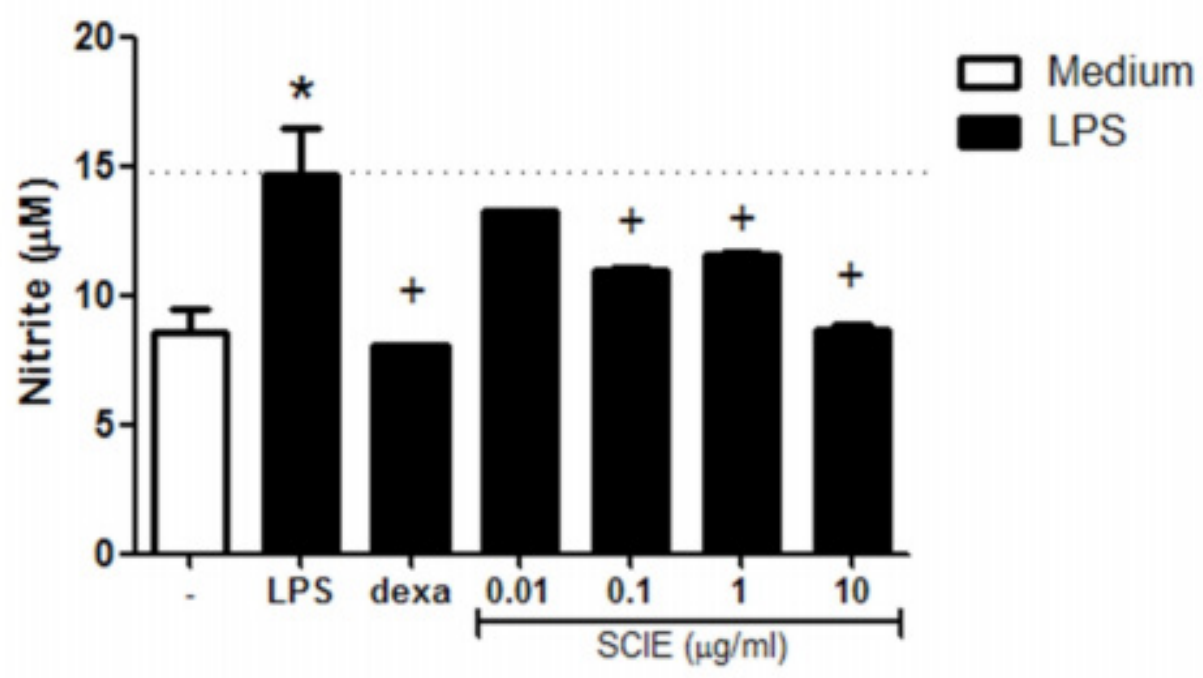

FIGURE 1 - Production of nitric oxide (NO) in J774A.1 cells treated with different concentrations of SCIE. The NO production was determined by the Griess reagent through the supernatant collected $24 \mathrm{~h}$ after the LPS simulation. The results were expressed as mean \pm standard error of the mean $(\mathrm{SEM}) . *$ indicates statistically significant difference $(\mathrm{p}<0.05)$ between stimulated group (LPS) and non-stimulated group (Medium); + indicates statistically significant difference between treated and untreated stimulated group (LPS). 
of neutrophils to the vascular endothelium (Tamura et al., 2009), as well as the low production of chemoattractant factors in the inflammatory site, without indication of which tissue cells were being down modulated in the production of these mediators (Goulart et al., 2007; Liz et al., 2008). Our results also confirm that the SCIE has pharmacological action on macrophages. This action may involve both inflammatory monocytes and/or activated resident-tissue macrophages, acting directly on the production of inflammatory mediators (such as NO) by these cells.

\section{Phytochemical constituents of the SCIE}

HPLC-UV-PDA analysis indicates that the SCIE contains $13.8 \%$ of flavonoids derived from quercetin and kaempferol, between aglycones and glycosides, considering the fact that the observed UV absorbance is a specific aglycone characteristic, and $23.1 \%$ for diterpenes, probably furan labdanes (Figure 2a). This analysis was confirmed by ESI-MSI analysis of the SCIE with ESI-Q-TOF-SIM, in positive mode, demonstrating characteristic pseudomolecular ions of these derivatives (quercetin: $303.23 \mathrm{~m} / \mathrm{Z}$; quercitrin: $449.37 \mathrm{~m} / \mathrm{Z}$; rutin: $611.51 \mathrm{~m} / \mathrm{Z}$; kaempferol: 287.23; afzelin: $433.37 \mathrm{~m} / \mathrm{Z}$; hyperoside: $465.37 \mathrm{~m} / \mathrm{Z}$ ), as well as the molecular ion of solidagenone $(317.16 \mathrm{~m} / \mathrm{Z})$ itself (Figure $2 \mathrm{~b}$ ), as previously shown by our group (Valverde et al., 2011). The TLC analysis confirmed the presence of flavonoids (such as quercetin) and terpenes (such as solidagenone).

The chemical analysis of the SCIE indicates that quercetin and its derivatives are the main constituents

A)

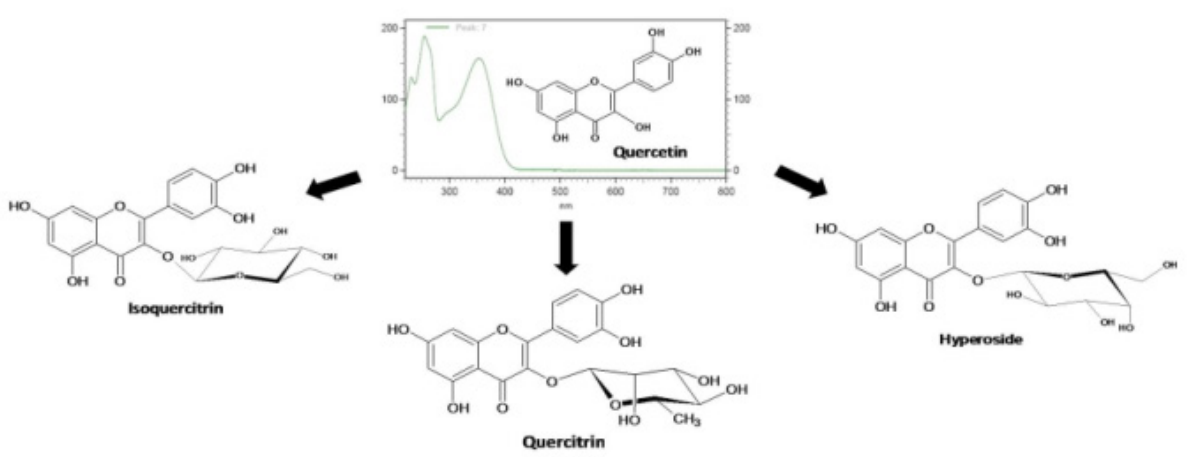

B)

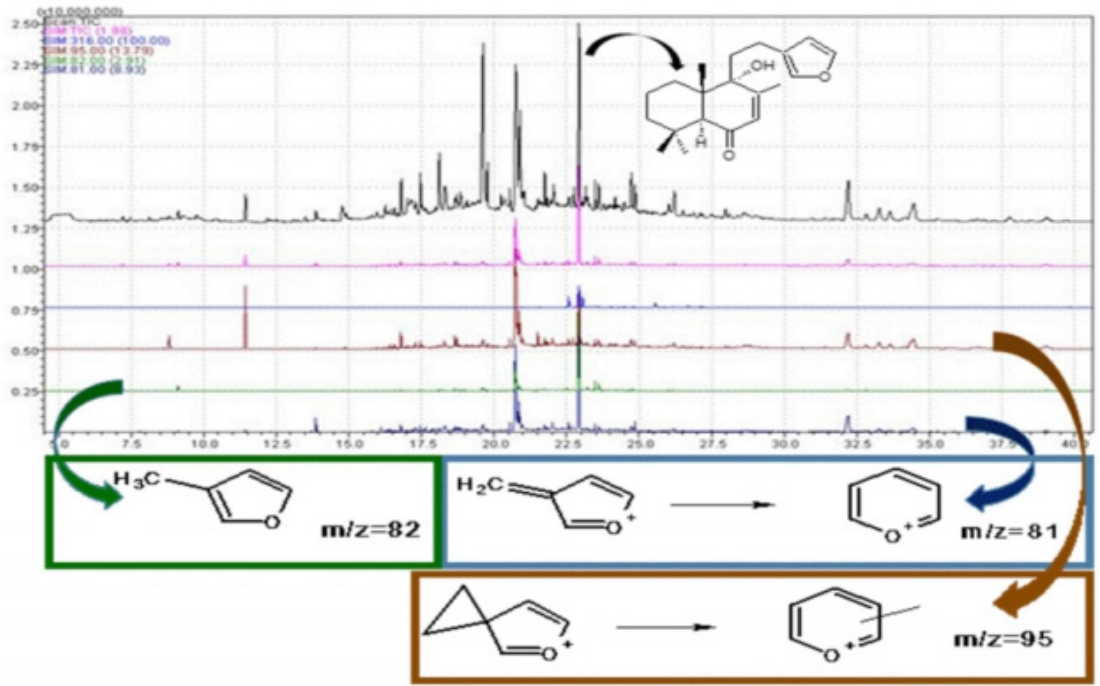

FIGURE 2 - Phytochemical constituents of the SCIE. UV from quercetin and their derivatives glycosides, all these substances were characterized in the HPLC-UV-PAD of SCIE (A). Inflorescences ether-ethanol extract total ion chromatogram (TIC) of solidagenone - the main labdane diterpene from $S$. chilensis - with selective-ion monitoring (B). 
present in the aerial parts of the plant. However, the presence of other substances, such as solidagenone and otherterpenoids, canactas potentiator of pharmacological activities or reduce possible toxic effects present in the extract. The anti-inflammatory activity of quercetin has previously been described in literature, demonstrating a significant decrease of inflammatory mediators (such as NO and TNF- $\alpha$ ) produced by activated macrophages (Manjeet, Ghosh, 1999; Mamani-Matsuda et al., 2006; Murakami et al., 2015; Li et al., 2018). These reductions were later associated with their immunomodulatory ability to inhibit the formation of the TLR4/MyD88/ PI3K complex that signals the transcriptional activation of pro-inflammatory genes such as NF-KB and AP-1 (Endale et al., 2013). Similar results were observed with kaempferol, which was able to modulate the production of proinflammatory enzymes and mediators such as NO, COX-1 and 2, IL-1 $\beta$ and TNF- $\alpha$ in LPS-stimulated RAW 264.7 cells (Lee, Kin, 2010).

\section{CONCLUSIONS}

The results present in this study suggest that the SCIE is potentially toxic to macrophages. Additionally, when taking into consideration the results of the tests conducted on nontoxic concentrations of this specific extract, there was a clear indication of anti-inflammatory effects through the inhibition of $\mathrm{NO}$ production by macrophages. The chemical analysis of SCIE, describing the main constituents as flavonoids derived from quercetin and kaempferol (13.8\%) and diterpenes, probably labdane $(23.1 \%)$, associate these metabolites with the observed anti-inflammatory activity. Other mediators such as cytokines and chemokines, as well as the signaling pathways and transcription factors expressed in activated macrophages in the inflammatory process may be targets of future studies to further understand the pharmacological action of inflorescences extract and compounds derived from $S$. chilensis.

\section{ACKNOWLEDGEMENTS}

The authors thank the Fundação Carlos Chagas Filho de Amparo à Pesquisa do Estado do Rio de Janeiro (FAPERJ), the Fundação para o Desenvolvimento Científico e Tecnológico em Saúde (FioTeC), Farmanguinhos and INCQS for financial support. The authors are also grateful to Bruna Carvalho for text correction.

\section{REFERENCES}

Apáti P, Szentmihályi K, Balázs A, Baumann D, Hamburger M, Kristo TSz, et al. HPLC analysis of the flavonoids in pharmaceutical preparations from Canadian goldenrod (Solidago canadensis). Chromatographia. 2002;56(1):S65-S68.

Assini FL, Fabrício EJ, Lang KL. Efeitos farmacológicos do extrato aquoso de Solidago chilensis Meyen em camundongos. Rev. Bras. Plantas Med. 2013;15(1):130-134.

Bagatini MD, Fachinetto JM, Silva ACda, Tedesco BT. Cytotoxic effects of infusions (tea) of Solidago microglossa DC. (Asteraceae) on the cell cycle of Allium cepa. Braz J Pharmacog. 2009;19(2B):632-636.

BRASIL. Ministério da Saúde. Agência Nacional de Vigilância Sanitária. Resolução da diretoria colegiada $n^{\circ} 166$, de 24 de julho de 2017. Dispõe sobre a validação de métodos analíticos e dá outras providências. Diário Oficial da União 25 jul 2017; Seção 1.

Corrêa, MP. Dicionário das plantas úteis do Brasil e das plantas exóticas cultivadas. Rio de Janeiro: Imprensa Nacional. 1984. vol. 6, p. 1926-1978.

De Freitas MV, Netto R de CM, Da Costa Huss JC, De Souza TMT, Costa JO, Firmino CB, et al. Influence of aqueous crude extracts of medicinal plants on the osmotic stability of human erythrocytes. Toxicol in vitro. 2008;22(1):219-224.

Endale M, Park SC, Kim S, Kim SH, Yang Y, Cho JY, et al. Quercetin disrupts tyrosine-phosphorylated phosphatidylinositol 3-kinase and myeloid differentiation factor- 88 association, and inhibits MAPK/AP-1 and IKK/ NF- B -induced inflammatory mediators production in RAW 264.7 cells. Immunobiology. 2013;218(12):1452-1467.

Facury Neto MA, Fagundes DJ, Beletti ME, Novo NF, Juliano Y, Penha-Silva N. Systemic use of Solidago microglossa DC in the cicatrization of open cutaneous wounds in rats. Brazilian Journal of Morp. 2004;21(4):204-210.

Goulart S, Moritz MI, Lang KL, Liz R, Schenkel EP, Frode TS. Anti-inflammatory evaluation of Solidago chilensis Meyen in a murine model of pleurisy. J Ethnopharmacol. 2007;113(2):346-353.

Lee JH, Kin GH. Evaluation of antioxidant and inhibitory activities for different subclasses flavonoids on enzymes for rheumatoid arthritis. J Food Sci. 2010;75(7):H212-217.

Li X, Jin Q, Yao Q, Xu B, Li L, Zhang S, et al. The flavonoid quercetin ameliorates liver inflammation and fibrosis by 
regulating hepatic macrophages activation and polarization in mice. Front Pharmacol. 2018;9:72.

Liz R, Vigil SVG, Goulart S, Moritz MIG, Schenkel EP, Fröde TS. The anti-inflammatory modulatory role of Solidago chilensis Meyen in the murine model of the air pouch. J Pharm Pharmacol. 2008;60(4):515-521.

Lorenzi H, Matos FJ de A. Plantas medicinais no Brasil: nativas e exóticas. $2^{\mathrm{a}}$ ed. São Paulo: Instituto Plantarum; 2008. $544 \mathrm{p}$.

Mamani-Matsuda M, Kauss T, Al-Kharrat A, Rambert J, Fawaz F, Thiolat D, et al. Therapeutic and preventive properties of quercetin in experimental arthritis correlate with decreased macrophage inflammatory mediators. Biochem Pharmacol. 2006;72(10):1304-10.

Manjeet KR, Ghosh B. Quercetin inhibits LPS-induced nitric oxide and tumor necrosis factor-alpha production in murine macrophages. Int J Immunopharmocol. 1999;21(7):435-443.

Martins MD, Marques MM, Bussadori SK, Mesquita-ferrari RA, Pavesi VCS, Wadt NS, et al. Citotoxicidade in vitro de extratos de arnica brasileira (Solidago microglossa) e arnica paulista (Porophyllum ruderale). Conscientiae Saúde. 2009;8(1):99-104.

Mors WB, Rizzini CT, Pereira NA. Medicinal plants of Brazil. Algonac: Reference Publications, 2000. 549 p.

Murakami Y, Kawata A, Ito S, Katayama T, Fujisawa S. Radical-scavenging and anti-inflammatory activity of quercetin and related compounds and their combinations against raw264.7 cells stimulated with porphyromonas gingivalis fimbriae. relationships between anti-inflammatory activity and quantum chemical parameters. In Vivo. 2015;29(6):701-10.
Oishi Y, Manabe I. Macrophages in inflammation, repair and regeneration. Int

Immunol. 2018;30(11):511-528.

Paula-Freire LIG, Malpezzi-marinho ELA, Molska GR, Kohn DO, Correa L, Marinho EAV. Evaluation of the Acute Toxicity of the Hydroalcoholic Extract of Solidago chilensis Meyen (Arnica Do Campo) in Mice. AJPCT. 2014;2(2):217-228.

Tamura EK, Jimenez RS, Waismam K, Gobbo-neto L, Lopes NP, Malpezzi-marinho EA, et al. Inhibitory effects of Solidago chilensis Meyen hydroalcoholic extract on acute inflammation. J Ethnopharmacol. 2009;122(3):478-85.

Valverde SS, Azevedo SS, Tomassini TCB. Utilização de CLAE, como paradigma na obtenção e controle do diterpeno solidagenona a partir de inflorescências de Solidago chilensis Meyen (arnica brasileira). Rev Bras Farm. 2009;90(3):196-199.

Valverde SS, Souza SP, Lima KSC, Oliveira TB, Lima ALS. Selective-ion monitoring in unequivocal identification of solidagenone in Solidago chilensis raw extracts. In: IV Congresso da Sociedade Brasileira de Espectrofotometria de Massas. São Paulo: The Royal Palm Plaza; 2011.

Wagner H, Bladt S. Plant Drug Analysis: A Thin Layer Chromatography. 2 ed. München: Springer-Verlag Berlin Heidelberg; 1996.

Zanetti GD, Manfron MP, Pagliarini VP, Morel AF. Toxicidade Aguda e Atividade Antibacteriana dos Extratos de Tropaeolum majus L. Acta Farm Bon. 2003;22(2):159-162.

Received for publication on $14^{\text {th }}$ November 2017 Accepted for publication on $20^{\text {th }}$ May 2019 